\title{
Prospective and Retrospective Study of Ovarian Tumors
}

\author{
G.R.Sumanlatha $^{1 *}$, K. Sumalatha ${ }^{2}$, P. Ramanakumari ${ }^{3}$, G. Saila Bala ${ }^{3}$ and A. Bhagyalaxmi ${ }^{1}$ \\ ${ }^{1}$ Department of Pathology, Andhra Medical College, Vishakhapatnam, \\ Andhra Pradesh State, India \\ ${ }^{2}$ Department of Pathology, Chalmedaanandrao Medical College, \\ Karimnagar, Telangana State, India \\ ${ }^{3}$ Department of Pathology, Guntur Medical College, Guntur, Andhrapradesh State, India
}

*Corresponding author

\section{A B S T R A C T}

\section{Keywords}

Ovarian tumors, Benign tumors, Borderline, Malignant.

\section{Article Info}

Accepted:

25 June 2016

Available Online:

10 July 2016
Ovarian neoplasms are the most fascinating tumors in terms of its histogenesis, clinical behavior and malignant potentiality. This study was done in Guntur medical college, Guntur over $5^{1 / 2}$ yrs from January 2005 to July2010.322 ovarian tumors were diagnosed. The incidence was $4.2 \%$ per year, age ranged from 7-80 yrs with the peak in the fourth decade. Benign tumors were $64 \%$, borderline tumors were $1.5 \%$ and malignant tumors were $34.5 \%$.Benign tumors were common in the younger age where as the malignant tumors were more common in the elderly. Surface epithelial tumors were $74.8 \%$, germ cell tumors were $16.5 \%$.Common benign ovarian tumor was serous cystadenoma and the common malignant tumor was serous cystadenocarcinoma. Cystic teratomas were common benign tumors of germ cell origin accounting for $10 \%$ of the total ovarian tumors. In the first decade the germ cell tumors are 100\% malignant. Sex cord stromal tumors were rare.3.4\% of ovarian tumors were metastatic.

\section{Introduction}

Ovarian tumors are the most common gynaecological neoplasms and $5^{\text {th }}$ most frequent cause of cancer death (Scully et al., 1998). Frequency of different ovarian tumors is different for western world and Asian countries.

Ovarian neoplasms cannot be detected early in their development due to their vague nonspecific symptoms which can go unrecognized for a period of time and as it is an intra-abdominal organ.
A female's risk at birth of having ovarian tumor sometime in her life is $6.0-7.0 \%$, of having ovarian cancer is almost $1.5 \%$ and dying from ovarian cancer is $1.0 \%$ (Day et al., 1997).

\section{Materials and Methods}

A Retrospective and Prospective study of Ovarian neoplasms was done in the Department of Pathology, Guntur Medical College, Guntur over a period of $51 / 2 y r s$ 
(from January 2005 to July 2010).All the cases of ovarian neoplasms registered at Guntur Medical College/ Government General Hospital, Guntur were taken for the study to analyse the age incidence, histologic variants, bilaterality and staging according to WHO and FIGO guidelines. Total number of retrospective cases were 217(from January 2005to May2008) prospective cases were 105 studied during 2 years period (from June 2008 to July 2010).

A total of 7744 gynaecological cases were received for histopathological examination in which 322 cases were recorded as ovarian neoplasms. The type of specimens were Total abdominal hysterectomy (TAH) with Bilateral salpingo-oophorectomy (BSO), TAH with unilateral salpingo-oophorectomy (SO), salpingo-oophorectomy (SO), Cystectomy, enucleation of the cyst, debulking of the tumor. A few cases with omental biopsies were also included in the study. The case details like age, presenting symptoms were recorded. For retrospective cases the paraffin blocks and H\&E stained sections from archives are reviewed and the gross features were noted from the registers. For the prospective cases routine grossing was done and representative tissue was submitted for microscopy. The sections were stained with routine haemotoxylin and Eosin. Special stains like PAS and reticulin were done wherever necessary.

\section{Results and Discussion}

Total of 322 ovarian tumors were diagnosed clinically and histopathologically. The incidence of ovarian tumors among total gynaecological specimens received in the $5^{1 / 2}$ years period is $4.2 \%$. The age incidence was $4^{\text {th }}$ decade followed by the $5^{\text {th }}$ and $3^{\text {rd }}$ decades. Benign tumors account for $64 \%$, borderline tumors $1.5 \%$ and malignant tumors $34.5 \%$ of total ovarian tumors.
Benign tumors were more common in the younger age where as the malignant tumors are more common in the elderly. Serouscystadenoma is the tumor that can occur at any age. Surface epithelial tumors were the common histological type accounting for $74.8 \%$ followed by the germ cell tumors $16.5 \%$. Benign $(51 \%)$ and malignant $(23 \%)$ surface epithelial tumors form the major group of total ovarian tumors. The most common benign ovarian tumor is the serous cystadenoma and the common malignant tumor is the serous cystadenocarcinoma. Germ cell tumors are the next common tumors after the surface epithelial tumors and more than $75 \%$ occur below third decade. Benign cystic teratomas are the common benign tumors of germ cell origin and account for $10 \%$ of the total ovarian tumors and more than $50 \%$ of the tumors noticed in the first two decades. In the first decade $100 \%$ of the germ cell tumors are malignant. Sex cord stromal tumors are the rare ovarian tumors in which fibromas are the common benign tumors and granulosa cell tumor is the commonest malignant sex cord stromal tumor.3.4\% of the ovarian tumors are metastatic.

Most of the tumors were right sided (53.4\%) and $(39 \%)$ are left sided. Bilaterality is observed in 25 cases $(7.7 \%)$ in which 12 cases were benign, 6 were malignant and 7 were metastatic tumors. One case $(0.9 \%)$ of sex cord stromal tumor and 1 case $(0.9 \%)$ of germ cell tumor showed metastatic tumor deposits. Ovarian tumors were staged by WHO criteria. Most of the tumos were in stage I $(71 \%)$ followed by stage III $(25 \%)$ and stage II (4\%). The prognosis of the tumor was correlated with the histologic type, grade and stage of the tumor.

During the present study a total of 7744 specimens received, of which $322(4.2 \%)$ cases are ovarian tumors (Table- 
1). A similar incidence of $3.7 \%$ was recorded from eastern (Indian Journal of cancer, July-September 2010) Asian countries and $4.5 \%$ in Saudi Arabia (Indian Journal of cancer, July-September 2010) whereas the incidenceis more than double in USA, accounting for $10.6 \%$ and $11.6 \%$ in Canada according to crude incidence rates, age standardized rates (ASR) of ovarian cancer and other uterine adnexal cancers.

A wide age range from 7-80 yrs was recorded in the present study. Peak incidence was noted in the $4^{\text {th }}$ and $5^{\text {th }}$ decade (Table-2). In a study by Kayastha et al., (Pilli et al., 2002) the age group ranged from 18-70 Yrs. The youngest patient recorded in the present study was $7 \mathrm{yrs}$ and the oldest patient was $80 y$ rs of age.

Benign tumors occured in all age groups and malignant tumors were common in elderly. In the present study serous cystadenoma is the tumor which occurred in all age groups (Table-5) and is comparable with a similar study done by Tavassoli (Ozols et al., 1997). Mature cystic teratoma accounted for half of ovarian neoplasms that appear in the first two decades of life.

Tumors categorized as benign were $64 \%$ (206/322), borderline tumors were $1.5 \%$ (5/322) and malignant tumors $34.5 \%$ (111/322) (Table-6). In a study by Pilli et al., (Auranen et al., 1996) from India 75.2\% of ovarian tumors are benign and in another study by Ahmed et al., (Bjorge et al., 1997) only $59.2 \%$ are benign. In a study from western countries where $75 \%-80 \%$ of ovarian tumors were benign.

Borderline tumors in the present study were $5(1.5 \%)$.But in a study from Sweden ${ }^{(8)}$ the borderline tumors were recorded as high as 14-15\% (Study of ovarian tumors in Nepal Medical College Teaching Hospital by $\mathrm{S}$ Kayastha, 2011; Ahmad et al., 2000;
Prabhakar et al., 1989) of primary ovarian neoplasms. They observed that the incidence of borderline tumors was increasing with concomittent decrease in the invasive malignancies (Prabhakar et al., 1989; Jha et al., 2008; SumairaYasmin et al., 2008).

In the present study, the malignant ovarian tumors recorded were $111(34.5 \%)$. In a study done by Pilli et al., $24.8 \%$ are malignant and Ahmed et al., recorded malignant tumors as $40.8 \%$.

Surface epithelial tumors are the commonest category of all the ovarian tumors. In the present study they constitute $74.8 \%$ of total ovarian tumors. In a similar study from Indi and Pakisthan they comprised $70.9 \%$ and $63.5 \%$ of all ovarian tumors respectively. The incidence is $50-55 \%$ of all ovarian tumors in western countries and $46-50 \%$ in Japan. This indicates that incidence of surface epithelial tumors varies from region to region.

In the present study, the benign surface epithelial tumors comprised $79.12 \%$ (163/206) of total benign ovarian tumors. In a study by $\mathrm{R}$ Jha et al., (2008) they accounted for $48.9 \%$ of all benign ovarian tumors.

Most serous tumors are benign and in the present study $61.78 \%$ (97/157) are benign. In the west $60 \%$ of serous tumors are benign. In a study by $\mathrm{R}$ Jha et al., $78.9 \%$ were benign. Our study is similar to the study of western countries.

Serous cystadenoma is the commonest benign tumor and it comprised $44.66 \%$ of (92/206) total benign tumors and it is comparable with the study done by $\mathrm{R}$ jha $e t$ al., in which $32.6 \%$ are serous cystadenomas. 
In the current study $2.43 \% \quad(5 / 206)$ are serous cystadeno fibromas of total benign tumors.

Mucinous tumors are the common tumors followed by the serous. In the present study they comprised about $21.11 \%$ (68/322) of total ovarian tumors and in a study by $\mathrm{R}$ jha et al., $16.8 \%$ are mucinous whereas this figure is $25.5 \%$ and $25 \%$ in other studies.

Mucinous cystadenomas in the present study account for $91.17 \%(62 / 68)$ of the total mucinous tumors and in a study by $\mathrm{R}$ Jha $e t$ al., $77.8 \%$ of mucinous tumors are benign. In west $75 \%$ of mucinous tumors are benign.

Other benign tumors in the present study are one case of Brenner and 3 cases of mixed benign surface epithelial tumors.

In the present study a rare case of seromucinous tumor with mural nodule was recorded.

In our present study five cases $(1.55 \%)$ of mixed tumors were reported. Out of these three were benign $(1.45 \%)$ and two cases $(1.80 \%)$ were malignant tumors. These were one case of seromucinous cystadenoma, one case of serous cystadeno fibroma, one case of seromucinous tumor with mural nodule, onecase of benign Brenner with serous cystadeno carcinoma, one case of seromucinous cystadenocarcinoma.

The borderline tumors recorded in the present study were $1.5 \%$ in which $60 \%$ were serous and $40 \%$ were mucinous. In the western countries incidence of borderline tumors is $10 \%$.

In our study 3 cases were reported as atypical proliferative serous tumors(APSTs), the age of the patients range from 13 to 58 yrs.

In the current study 2 cases were diagnosed as atypical proliferative mucinous tumors. The age of the patients were $41 \mathrm{yrs}$ and $65 y$ rs.

In the present study, out of all malignant tumors the percentage of malignant surface epithelial tumors was $65.8 \%$ (73/111)In a study by R Jha et al., it is $69.23 \%$ but in the western world $90 \%$ are malignant.

The serous tumors were the common ( 36.3 $\%)$ malignant tumors. This figure in other studies is $21.42 \%$.

Serous cystadenocarcinomas were the common malignant tumors and they constituted $51.35 \%(57 / 111)$ of all malignant tumors in the present study and they accounted for $46.2 \%$ of all ovarian malignancies. In a study by $\mathrm{R}$ Jha and in western countries $30 \%$ were malignant.

Mucinous cystadenocarcinomas in the present study accounted for (4/68) 5.88\% of all mucinous tumors and it is $22.2 \%$ in other studies. The other malignant surface epithelial tumors in the current study were endometrioid (8.2\%), malignant Brenner $(1.36 \%)$, Malignant mixed mullerian tumors $(4.1 \%)$

In the present study 6 cases (5.4\%)were diagnosed as endometrioid adenocarcinoma. In a study by Sumaira et al., (2002) it is $28.5 \%$.

In our study $1(0.3 \%)$ case of malignant Brenner tumor was reported Malignant Mixed Mullerian Tumors comprised less than $1 \%$ of ovarian tumors. There were 300 cases in the literature. The mean age group was 60 yrs.In our study 3(0.9\%)cases were reported as MMMT and in which 2 cases were of the age 40yrs and 1 case is at the age of 62yrs.MMMT's areaggressive, with a median survival of approximately 1 year. The tumors of Sex-cord stromal types 
observed in this study was $4.65 \%$ in which $53 \%$ were dignosed as benign and $47 \%$ were malignant. In a study by $\mathrm{R}$ Jha et al., sex cord stromal tumors are $3 \%$ of all ovarian tumors which is less in comparision with the present study. In the benign category, the most commonly observed tumor is fibroma which is $40 \%$ of all sex cord stromal tumors and $6.6 \%$ each of fibro-thecoma and thecoma. Under the malignant tumors, all were granulosa cell tumors, which constituted $2.17 \%$ (7/322) of all ovarian tumors. They accounted for $0.62 \%$ of all ovarian tumors in a study by $\mathrm{R}$ Jha et al. In the present study 4 cases $(57 \%)$ of adult granulosa celltumor and 3 cases $(43 \%)$ of Juvenile granulosa tumors were dignosed.

Adult granulosa cell tumors are the low grade malignant tumors and they constitute (4/322) $1.2 \%$ of all ovarian tumors. In the present study they occurred in age group of $45 \mathrm{yrs}$ ( 2 cases), $60 \mathrm{yrs}$ (1case) and in $30 \mathrm{yrs}$ (1case). All the tumor, in the current study are unilateral.

3 cases of Juvenile granulosa cell tumors were diagnosed, the age ranged from 12 to 18 yrs.

The incidence of germ cell tumors in the present study was $16.5 \%$ (53/322) of all ovarian tumors which correlates with a similar study from Asian countries ${ }^{7}$ where it is observed as $11 \%-16.8 \%$ but the incidence of germ cell tumors was observed as high as $30 \%$ of all ovarian tumors in western countries.

The majority of germ cell tumors in the present study were mature cystic teratomas, constituting $62.26 \%$ of all germ cell tumors. In a similar study $95.58 \%$ of germcell tumors were benign. In the current study 1 case of mature cystic teratoma with mucinous cystadenoma was reported. Malignant germ cell tumors in the present study were $18.01 \%$ of all malignant tumors. In a study by $\mathrm{R}$ Jha and Karki $11.5 \%$ are malignant. The common malignant germ cell tumors in the present study were Dysgerminoma (40\%), Mixed germ cell tumors(35\%), Yolksac tumor(10\%), Immature teratoma, teratocarcinoma, Teratoma with malignant transformation $(5 \%)$.

Dysgerminoma is an uncommon tumor accounting for $1-2 \%$ of primary ovarian neoplasms and $3-5 \%$ of ovarian malignancies. The tumor can occur at any age from 7 months to $70 \mathrm{yrs}$. In our study 1 case of dysgerminoma occurred at the age of 7 yrs. Grossly, dysgerminoma is usually unilateral more often in the right ovary which is involved in approximately $50 \%$ of cases. In the current study $75 \%$ are present in the right ovary which correlates with the literature.

Microscopically dysgerminoma composed of aggregates, islands or strands of large uniform cells surrounded by varying amounts of connective tissue stroma containing lymphocytes. The cells are large, contain oval to round nuclei and ample amount of pale, slightly granular eosinophilic or clear cytoplasm.

Mixed germ cell tumors are composed of more than one neoplastic germ cell element such as dysgerminoma combined with teratoma, yolksac tumor, choriocarcioma, embryonal carcinoma or polyembryoma..

Immature teratomas are composed of tissues derived from the three germ cell layersand in contrast to the much more common mature teratoma, they contain immature or embryonal structures.

Teratoma with malignant transformation is an uncommon complication of mature cystic teratoma. It occurs in approximately $2 \%$ of 
cases. The age in the literature ranges from 10 to 88 yrs. In the present study the age of the patient is $45 \mathrm{yrs}$. In the present study one case $(0.9 \%)$ was reported as Teratocarcinoma.

Yolksac tumor is being diagnosed with much greater frequency nowadays and is the second most common malignant ovarian germ cell neoplasm after dysgerminoma. Grossly yolksac tumors are unilateral, it has the predilection to the right ovary. In our study 2 cases are diagnosed as yolksac tumors which are right sided. The tumor size ranges from $10-12 \mathrm{~cm}$, which is round to oval, globular, smooth gray yellow to reddish brown areas because of haemorrhage, with solid and cystic areas on cut section.

Microscopically, it exhibits a wide range of histologic patterns predominantly microcystic, endodermal sinus, glandular, macrocystic patterns and myxomatous pattern. The cells have large,slightly vesicular nuclei, prominent nucleoli and show mitotic activity. The surrounding capsular sinusoid space is lined by single layer of cells with prominent hyperchromatic nuclei. The eosinophilic, hyaline droplets may be present either within the tumor cells or outside them, they may be numerous and prominent in some tumors.

In the present study 2 cases $(0.62 \%)$ were diagnosed as leiomyomas.

The ovary is a common site of metastases from other primary malignant tumors. The most common primary origins are the breast, colon and stomach. In the present study $3.42 \%(11 / 322)$ were diagnosed as metastatic. In a study by $\mathrm{R}$ jha et al., they accounted for $2.4 \%$ of all ovarian tumors.

In a study in Korean population the incidence of metastatic ovarian malignancies account for $13.6 \%$ of all ovarian malignancies, which is higher than that in Europe and North America. Out of all metastatic tumors $7(63.63 \%)$ cases were bilateral. In the current study $63.63 \%$ metastatic tumors were bilateral.

Table.1 Age Incidence of Ovarian Tumors

\begin{tabular}{|c|c|c|c|c|c|c|c|c|c|}
\hline Year & $\mathbf{0 - 1 0}$ & $\mathbf{1 1 - 2 0}$ & $\mathbf{2 1 - 3 0}$ & $\mathbf{3 1 - 4 0}$ & $\mathbf{4 1 - 5 0}$ & $\mathbf{5 1 - 6 0}$ & $\mathbf{6 1 - 7 0}$ & $\mathbf{7 1 - 8 0}$ & Total \\
\hline 2005 & 1 & 7 & 8 & 15 & 12 & 11 & 3 & - & 57 \\
\hline 2006 & - & 11 & 9 & 18 & 10 & 12 & 2 & - & 62 \\
\hline 2007 & 1 & 6 & 21 & 17 & 22 & 9 & 4 & 1 & 81 \\
\hline 2008 & - & 1 & 5 & 12 & 19 & 12 & 4 & 2 & 55 \\
\hline 2009 & - & 5 & 10 & 9 & 8 & 3 & 2 & - & 37 \\
\hline $\begin{array}{c}\text { July } \\
2010\end{array}$ & - & 2 & 5 & 9 & 8 & 5 & - & 1 & 30 \\
\hline Total & $\begin{array}{c}2 \\
(0.62 \%)\end{array}$ & $\begin{array}{c}32 \\
(9.94 \%)\end{array}$ & $\begin{array}{c}58 \\
(18.01 \%)\end{array}$ & $\begin{array}{c}80 \\
(24.84 \%)\end{array}$ & $\begin{array}{c}79 \\
(24.53 \%)\end{array}$ & $\begin{array}{c}52 \\
(16.15 \%)\end{array}$ & $\begin{array}{c}15 \\
(4.66 \%)\end{array}$ & $\begin{array}{c}4 \\
(1.24 \%)\end{array}$ & $\begin{array}{c}322 \\
(100 \%)\end{array}$ \\
\hline
\end{tabular}

In the present study the maximum number of ovarian tumors were seen in the age group of 31-50 years and constitute almost $49.37 \%$ of total tumors. 
Fig.1 Histological types of Ovarian Tumors/year

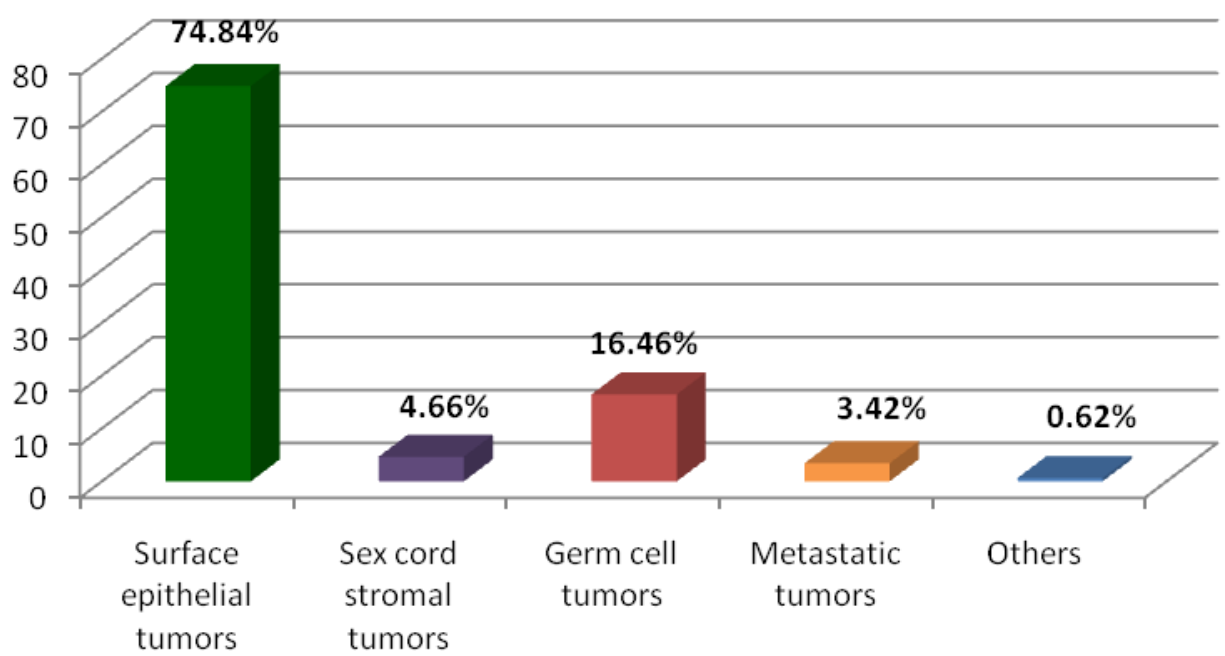

Table.2 Age incidence of Benign Ovarian Tumors

\begin{tabular}{|c|c|c|c|c|c|c|c|c|c|}
\hline Histologic type & $\begin{array}{l}< \\
1 \\
0\end{array}$ & $11-20$ & $21-30$ & $31-40$ & $41-50$ & $51-60$ & $61-70$ & $71-80$ & Total \\
\hline $\begin{array}{c}\text { Serous } \\
\text { cystadenoma }\end{array}$ & & 6 & 21 & 27 & 21 & 11 & 3 & 3 & $92(44.66 \%)$ \\
\hline $\begin{array}{c}\text { Mucinous } \\
\text { cystadenoma }\end{array}$ & & 6 & 9 & 19 & 16 & 9 & 3 & & $62(30.09 \%)$ \\
\hline $\begin{array}{c}\text { Serous } \\
\text { cystadenofibroma }\end{array}$ & & & 1 & 1 & 2 & 1 & & & $5(2.42 \%)$ \\
\hline Benign Brenner & & & & 1 & & & & & $1(0.48 \%)$ \\
\hline $\begin{array}{l}\text { Mixed surface } \\
\text { epithelial tumor }\end{array}$ & & 1 & & 1 & 1 & & & & $3(1.45 \%)$ \\
\hline Thecoma & & & & & 1 & & & & $1(0.48 \%)$ \\
\hline Fibroma & & 1 & & 2 & 2 & 1 & & & $6(2.92 \%)$ \\
\hline Fibro-thecoma & & & & & & & 1 & & $1(0.48 \%)$ \\
\hline Dermoid cyst & & 6 & 17 & 5 & 5 & & & & $33(16.01 \%)$ \\
\hline Leiomyoma & & & & 1 & & 1 & & & $2(0.97 \%)$ \\
\hline Total & - & $\begin{array}{c}20 \\
(9.70 \%)\end{array}$ & $\begin{array}{c}48 \\
(23.30 \%)\end{array}$ & $\begin{array}{c}57 \\
27.6 \%)\end{array}$ & $\begin{array}{c}48 \\
(23.3 \%)\end{array}$ & $\begin{array}{c}23 \\
11.1 \% \\
\end{array}$ & $\begin{array}{c}7 \\
(3.3 \%) \\
\end{array}$ & $\begin{array}{c}3 \\
(1.4 \%)\end{array}$ & $\begin{array}{c}206 \\
(100 \%)\end{array}$ \\
\hline
\end{tabular}

The incidence of the benign tumors was more common in the $4^{\text {th }}$ decade 
Table.3 Age incidence of Malignant Tumors

\begin{tabular}{|c|c|c|c|c|c|c|c|c|c|}
\hline Histologic type & $0-10$ & $11-20$ & $21-30$ & $31-40$ & $41-50$ & $51-60$ & $61-70$ & 71-80 & Total \\
\hline $\begin{array}{l}\text { Serous } \\
\text { cystadenocarcinoma }\end{array}$ & - & - & - & 12 & 20 & 21 & 3 & 1 & 57 \\
\hline $\begin{array}{l}\text { Mucinous } \\
\text { cystadenocarcinoma }\end{array}$ & & & 1 & 2 & 1 & & & & 4 \\
\hline $\begin{array}{l}\text { Endometrioid } \\
\text { adenocarcinoma }\end{array}$ & & & & 1 & & 3 & 2 & & 6 \\
\hline Malignant Brenner & & & & & 1 & & & & 1 \\
\hline $\begin{array}{l}\text { Malignant Mixed } \\
\text { surface epithelial }\end{array}$ & & & & & 2 & & & & 2 \\
\hline MMMT & & & & 2 & & & 1 & & 3 \\
\hline Dysgerminoma & 1 & 3 & 3 & 1 & & & & & 8 \\
\hline Mixed germ cell & 1 & 3 & 3 & & & & & & 7 \\
\hline \begin{tabular}{|l} 
Yolk sac \\
\end{tabular} & & 2 & & & & & & & 2 \\
\hline Teratocarcinoma & & & & 1 & & & & & 1 \\
\hline $\begin{array}{l}\text { Teratoma with } \\
\text { malignant } \\
\text { transformation }\end{array}$ & & & & & 1 & & & & 1 \\
\hline Immature Teratoma & & & 1 & & & & & & 1 \\
\hline Adult granulosa & & & 1 & & 2 & 1 & & & 4 \\
\hline Juvenile granulosa & & 3 & & & & & & & 3 \\
\hline Krukenberg & & & 1 & 3 & 1 & 1 & 1 & & 7 \\
\hline $\begin{array}{l}\text { Adenocarcinoma } \\
\text { deposit }\end{array}$ & & & & 1 & 1 & 2 & & & 4 \\
\hline Total & 2 & 11 & 10 & 23 & 29 & 28 & 7 & 1 & 111 \\
\hline
\end{tabular}

Malignant tumors were more common in the $5^{\text {th }}$ and $6^{\text {th }}$ decade in the present study. 


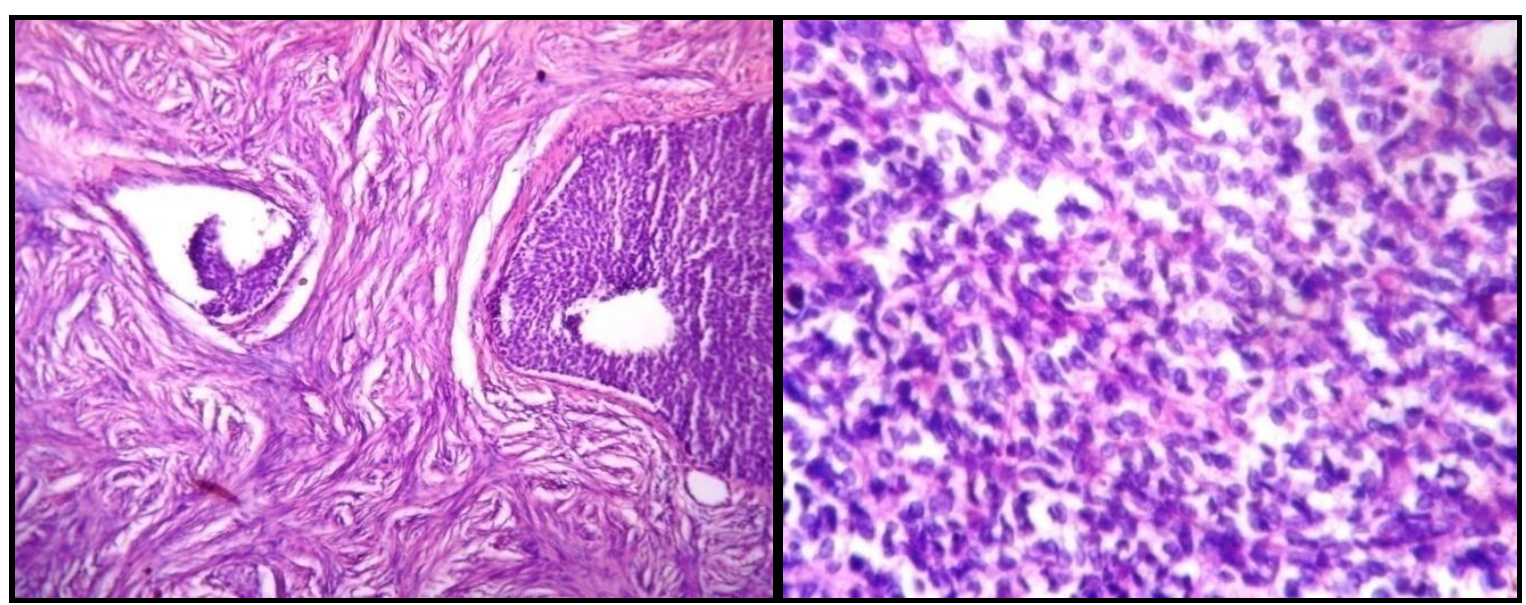

Figure.2 Brenner Tumor

Figure.3 Adult Granulosa Cell Tumor

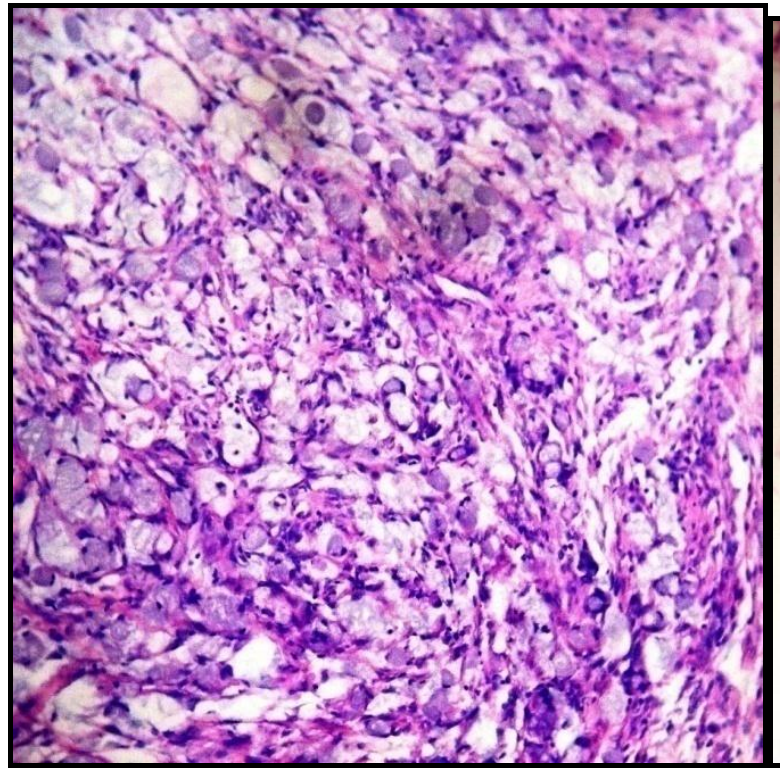

Figure.4 Krukenberg Tumor

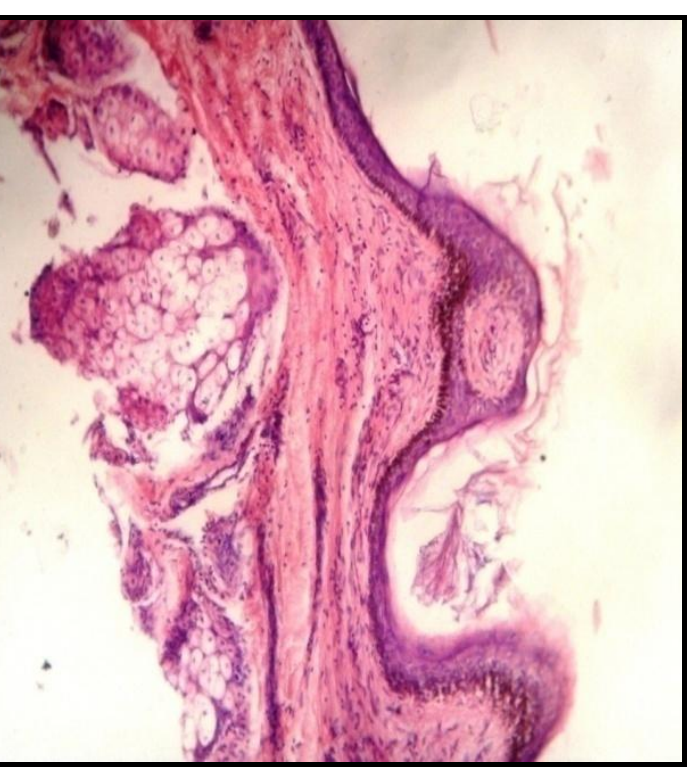

Figure.5 Mature Cystic Teratoma
Total of 11 cases, Krukenberg tumors were $63.63 \%$ (7/11) adenocarcinomas were $36.37 \%$ (4/11). In these metastatic tumors primary was detected in only 2 cases and in the rest of the 9 cases primary was unknown.

In our study bilaterality was observed in 17 cases of surface epithelial tumors, and 1 case of mixed ovarian tumor i.e teratoma and mucinous cystadenoma and in 7 metastatic tumors.
In the present study tumor deposit is shown most commonly in the omentum, peritoneum, tube, other ovary and other sites. The tumor deposit is shown mostly by the surface epithelial tumors.

Staging of the ovarian tumors was the most important criteria for the prognosis of the individual. In the present study all the ovarian tumors were staged with the parameters like capsular breach, tumor deposit in the other ovary, tube, peritoneum, 
omentum, ascitic fluid etc. Most of the tumors in the present study were in stage I (71\%), followed by the stage III $(25 \%)$ and in stage II only few (4\%) cases were seen.

\section{References}

Ahmad, Z., Kayani, N., Hasan, S.H. et al. 2000. Histological pattern of ovarian neoplasm. J. Pak. Med. Assoc., 500: 416-9.

Auranen, A., Grenman, S., Makinen, J., Pukkala, E., Salmi, T. 1996. Borderline ovarian tumorsin Finland :epidemiology and familial occurence. Am. $J$. Epidemiol., 144: 548- 53.

Bjorge, T., Engeland, A., Hansen, S., Trope, C.G. 1997. Trends in incidence of ovarian cancer and borderline tumors in Norway, 1954-1993, Int. J. Cancer, 71: 780-6.

Clinico histological pattern of ovarian tumors in Peshawar region by SumairaYasmin, AimanYasmin, Mohammad Asif from $J$. Ayub. Med. Coll. Abdoottabad, 20(4).

Day, N.E., Krishnan, E. Epidemiology of gynaecological cancers. Gynaecologyby Shaw R W.2nd ed. Edinburgh: Churchill Living Stone, p 477-87.

Idelson, M.G. Malignancy in Brenner tumors of the ovary, with comments on histogenesis and possible estrogen production. Obstet. Gynecol. Surg. Indian J. cancer/July-September 2010 /volume 47/ Issue 3.

Ozols, R.F., Rubin, S.C., Thomas, G., Robboy, S. 1997. Epithelial ovarian cancer, in:Hoskins WJ, Perez CA, Young RC, eds. Principles and practice of gynecologic oncology, $\quad 2^{\text {nd }} e d n$.
Philadelphia, PA: Lippincott- Raven, 919-86.

Pilli, G.S., Suneeta, K.P., Dhaded, A.V., Yenni, V.V. 2002. Ovarian tumors:a study of 282 cases, J. Indian Med. Assoc., 100(420): 423-4.

Prabhakar, B.R., Maingi, K. 1989. Ovarian tumours- prevalence in Punjab. Indian J. Pathol. Microbiol., 32: 276-81.

Jha, R., S. Karki. 2008. Study on Histological pattern of ovarian tumors and their age distribution. Nepal Med. Coll. J., 10(2): 81-85.

Scully, Robert, E., Young, Robert, H., Clement, Philip, B. 1998. Atlas of tumor pathology. Tumors of the ovary, maldeveloped gonads, fallopian tube and broad ligament. 3 Murad A. Ovulation induction and ovarian tumors: the debate continues. J. Pak. Med. Assoc., 48: 353-6.

Skirnisdottir, I., Garmo, H., Holmberg, L. 2007. Non -genital tract metastases tothe Ovaries presented as ovarian tumors in Sweden1990-2003: occurrence, origin and survival compared to ovarian cancer. Gynecol. Oncol., 105: 166-71.

Study of ovarian tumors in Nepal Medical College Teaching Hospital by $\mathrm{S}$ Kayastha. Nepal Med. Coll. J., 11(3): 200-202.

Tavassoli, F.A., Devilee, P. 2003. WHO classification of Tumors.Pathology and Genetics, Tumors of Breast and Female Genital Organs. IARC Pres: Lyon.

Young, R.H., Scully, R.E. 2002. Metastatic tumors of the ovary .In:Kurman RJ, editor. Blaustein's pathology of the female genital tract. $5^{\text {th }}$ ed New York: Springer; pp.1063-1101.

\section{How to cite this article:}

Sumanlatha, G.R., K. Sumalatha, P. Ramanakumari, G. Saila Bala and Bhagyalaxmi, A. 2016. Prospective and Retrospective Study of Ovarian Tumors. Int.J.Curr.Microbiol.App.Sci. 5(7): 741-750. doi: http://dx.doi.org/10.20546/ijcmas.2016.507.085 